\section{GRAHAM M.S. DANN}

Kad me je Nevenka Čavlek, glavna urednica ovog časopisa, zamolila da napišem nekrolog za Graham Danna, trenutno sam odlučila pristati pa čak i odgoditi svoje neposredne obaveze jer sam imala nekoliko osobnih razloga. Prvi je bio taj što sam dobila dozvolu da se odmaknem od anonimnog konvencionalnog stila kakav se često nalazi u nekrolozima s puno sitnih detalja u sjećanjima, a drugi je bio istinita veza i značenje koji su bili potrebni za prisjećanje članka koji smo Graham i ja objavili u ovom časopisu (Dann, G.M.S., Liebmann Parrinello, G., (2007). Od putopisa do ,putobloga“: Redefiniranje identiteta turista. Acta Turistica. Vol. 19, No. 1, str. 7-29). Povrh toga, nakon razmišljanja na dubljoj teoretskoj razini dok pišem ove retke i pokušavajući povlačiti konce s desetogodišnjim razmakom, shvatila sam da je članak koji prati razvoj od putopisa do putobloga zapravo bio neka vrsta prekretnice u Grahamovom prikazivanju kako se autoritarna organizacija mijenja pod utjecajem prakse.

Ustvari, prvi puta sam stupila u kontakt s Grahamom na početku 90-ih kada sam predala moj prvi zahtjevan rad na engleskome jeziku u Annals of Tourism Research (gdje je on bio urednik) na temu motivacije i anticipacije 1993. godine i kada mi je savjetovao pročitati Tourist as Child, njegovu knjigu iz 1989. godine koju još nisam poznavala. Uzgred, mnogi su znanstvenici, a posebno doktorandi, prepoznali njegovu rigoroznu znanstvenu prozu ne samo kao uobičajene bibliografske natuknice, nego kao izraz njegove posebne reputacije kao majstora turističkih znanosti. Taj članak, koji smo skupa napisali, u kojem su se prožimali njegovi osnovni interesi za jezik turizma na strogo znanstvenoj razini i moguće traganje za paradigmom, pratila su manja istraživanja u kojima su se

\section{GRAHAM M.S. DANN}

When I was asked by Nevenka Čavlek, the editor-in-chief of this journal, to write an obituary for Graham Dann, I immediately decided to accept it because of several reasons involving me more than the immediate duties that I had to postpone. The first one was to be granted a possible distancing from the anonymous conventional style of the usual obituaries full of detailed little memories and the second was a genuine link and significance that would require remembering an article written together by Graham and me many years ago and published by this journal (Dann, G.M.S., Liebmann Parrinello, G., (2007). From Travelogue to Travelblog: (Re)-negotiating tourist identity. Acta Turistica. Vol. 19, No. 1, pp. 7-29). Moreover, reflecting at a deeper theoretical level while writing these lines and trying to pull the strings at the distance of approximately a decade, I realized that the article tracing the way from travelogues to travel blogs represented a kind of a turning point in Graham's presentation of the authoritarian organization moved by industry.

In fact I first got in touch with Graham at the beginning of the 90ies after submitting to the Annals of Tourism Research (where he was the editor) my first strenuous English article on motivation and anticipation (1993), when he suggested that I consult his book Tourist as Child (1989) which I had not read yet. Actually, not only the more usual bibliographical cues but also the invitation to a rigorous scientific prose have been acknowledged by many scholars, especially Ph.D. candidates, as an aspect of his reputation of a master in tourism studies. That co-authored article, coupling his primary interest in the language of tourism at a rigorous scientific level and a possible search for a paradigm, was accompanied by smaller explorations 
otkrivali različiti turistički prizori. Najvažnije su bile brošure koje su dozvoljavale sociološkim aspektima realnosti izranjanje među piramidama monarhije top menadžera. Od poslušnog djeteta do vrhunskog menadžera, do nezavisne prosudbe odrastanja turista, do dijaloga i trialoga u članku koji je prezentiran u Kini 2005. godine, do triarhije iz 1995. godine i kasnije. Posve sigurno bilo je to $\mathrm{u}$ skladu s razvojem turizma na jednoj strani i psihologije turista kao gospodara (padrone) putem novih medija na drugoj strani. Slučajno sam tog ljeta imala priliku prezentirati putoblog kineskim studentima u Guandongu zadivljenima zbog nove mogućnosti za novog turista da bira, prosuđuje i komunicira na svoj način.

Suradnja s Grahamom putem elektroničke pošte postala je navika u zadnjih desetak godina, ali uvijek je bila popraćena komentarima na političke događaje, putovanja ili druge zgode. Turistički svijet se uvelike promijenio ovoga milenija kroz recipročno osnaživanje međunarodnog turizma i globalizacije; čvrsta je preporuka došla iz Research Committee 50 (RC 50) pod nazivom "International Tourism" ISA koja se sastaje svake četiri godine, iako stalno komuniciraju na temelju razvoja različitih disciplina u proučavanju turizma od najtradicionalnijih do najnovijih pristupa u i izvan trans-postdisciplinarnosti. Čak i u tom okviru, RC 50 se nekad mogao činiti poput opkoljene utvrde gubeći svoj izvorni plurilingvistički karakter (engleski, francuski i španjolski). To je štetilo europskim zemljama čija je sjajna sociološka prošlost ostala nepoznata, ili namjerno zanemarivana od strane anglosaksonskih, uglavnom jednojezičnih centara studija turizma. Osjećajući kao neku vrstu svoje misije i neznajući veličinu izazova, Graham i ja smo pokrenuli zahtjevan projekt stvaranja antologije The Sociology of Tourism, s podnaslovom European Origins and Developments. Uvod je bilo lakše napisati budući da smo se složili oko većine pitanja, ali teoretske i ideološke prepreke rojile su se posvuda, a najvažnija se exposing diverse tourism scenes. Paramount were the brochures letting out the sociological aspects of reality in-between the pyramid of a monarchy of top-managers. From the obedient child to the top-manager to the independent judgement of the tourist maturing, to a dialogue, and a trialogue in the paper presented in China in 2005, to the thriarchy of 1995 and later, it was certainly acceptable to the developments of the industry on the one hand and of the psychology of the tourist becoming the owner (padrone) through the new media, on the other. By luck in the same summer I also had the opportunity to present the dimension of the travel blog to the astonished Chinese students in Guandong who were pleased with this new possibility for the new tourist to make taking his/her choice, judge and communicate.

Working together via email with Graham became a habit in the last decade, but was also accompanied by comments on political events, travels, or other events. The world of tourism industry had changed a lot through the millennium in a reciprocal strengthening of international tourism and globalization; a solid reference was given by the Research Committee 50 (RC 50) under the title "International Tourism" of the ISA which meets every four years, but is continuously in touch due to the evolvement of different disciplines of tourism from the most traditional to the most recent approaches in and outside the trans-postdisciplinarity. Even in this framework, RC 50 could sometimes resemble a sieged fortress losing its original plurilinguistic character (English plus French and Spanish) along the way. This turned out to be damaging to the European countries whose glorious historical sociological past was not known or deliberately ignored by the Anglo-Saxon, mostly monolingual, centres of tourism studies. Feeling a kind of a mission and ignoring how challenging it would have become, Graham and I put together a demanding project: an anthology entitled The Sociology of Tourism, subtitled European 
odnosila na jaz između britansko-američkog i europskog pristupa koji se najjasnije potvrđivao u lingvističkim aspektima.

N.B. značenje "europskog", iako često korištenog, postalo je sasvim neriješeno u našoj elektronskoj prepisci tijekom dugotrajnog uređivanja knjige. Riječ "europski=0" činilo se da ne obuhvaća Englesku (ili Veliku Britaniju?) i odnosilo se na Kontinentalnu Europu uz odnos prema Engleskoj u kom se anticipirala debata o Brexitu. Ipak, glavni su se osnivači RC 50, Dann i Lanfant, pokazali u najboljem svjetlu. Paradoksalno, ali Marie-Françòoise Lanfant je bila ta koja je pomogla pronaći izlaz iz tunela, podsjećajući na osnovnu englesku komponentu turista i putnika iz Engleske u 18. stoljeću, dok se Graham protivio bilo kojoj vrsti jednojezičnosti. S obzirom da je od šeste godine učio klasične jezike, usprotivio se opasnoj dominaciji engleskoga jezika, prvo potiho, a kasnije i žestoko. Dakako, činjenica da mu je engleski bio materinji jezik olakšala je odnose s izdavačima i uvećala je njegov doprinos $\mathrm{u}$ velikom broju referenci za knjigu koju smo zvali kotao. Sporazumi sa znanstvenicima iz devet zemalja bili su plodonosni, ali ponekad sam bila zamoljena prevoditi više iz jednog $\mathrm{u}$ drugi mentalitet nego s jednog na drugi jezik. Tako su neki urednici iz raznih europskih zemalja komentirali da su više saznali o svojoj povijesti i kulturi.

Nedavno, kad je časopis Anatolia zamolio Grahama da napiše portret Marie-Françòoise Lanfant, ponudio mi je suradnju jer sam često bila posrednik u njihovom ne baš laganom odnosu. Članak smo završili tijekom kratkog odmora (s našim bračnim partnerima) na neuobičajenoj susnježici u Sorrentu, a ja ga se sjećam kako je svojoj ženi Elizabeth, o kojoj se predano brinuo zbog narušenog vida, pokušao objasniti neobičan prizor Vezuva pokrivenog snijegom.

Na kraju bih spomenula članak koji su Elizabeth i Graham publicirali u Festschrift (2017) za Marinellu Rocca Longo, directoricu našeg poslijediplomskog studija Master in
Origins and Developments. The introduction was less difficult than the whole enterprise as we mostly agreed on many issues, but theoretical and ideological obstacles nested everywhere, and the most relevant of them was the British-American vs. European divide finding its confirmation in the linguistic aspect.

$N . B$. although commonly used, the significance of 'the European' emerged as a totally unsettled question in our email exchange during the long editing of the volume. The word "European=0" seemed not to embrace England, (or Great Britain?) being interpreted as Continental Europe, with attitudes towards England that seemed to anticipate the Brexit debate. Still, both founding fathers of RC 50 Dann and Lanfant, showed their best face; paradoxically it was just Marie-Françòoise Lanfant who helped out of the tunnel, reminding of the essential English component of English tourists and travellers in the 18th century, while Graham was against every kind of monolingualism. Having started learning ancient languages at the age of 6 , he declared himself against the dangerous dominance of the English language first marginally and later on vigorously. However, having English as a mother tongue he facilitated the relationships with the publisher and contributed with an incredibly great number of references to the volume we used to call cauldron. The contacts with the scholars of the nine European countries were productive and created many encounters, but I was sometimes asked to translate more to/from different cultures or formae mentis rather than from/to languages. Thus, some editors from different European countries commented they had gained more consciousness of their own history and society.

Most recently, when Graham was offered by the Journal Anatolia to sketch a portrait of Marie-Françòoise Lanfant, he wanted to share it with me as I often acted as trait-d'union in their rather uneasy relationship. The article was finished during a 
Linguaggi del Turismo e comunicazione interculturale na Sveučilištu Roma Tre gdje je Graham imao puno studenata. Isto vrijedi za ostala sveučilišta u Italiji, naročito fakultete engleskoga jezika, na kojima se njegova knjiga na temu jezika turizma smatra temeljnom pa je i prevedena, a što mu je donijelo brojne pozive na intervjue i predavanja.

Giuli Liebman Parrinello short holiday (with the respective spouses) under an exceptional sleet in Sorrento when I remember him trying to explain to Elizabeth, his eye-impaired wife to whom he was a devoted carer, the peculiar sensation of the Vesuvio covered with snow.

I would like to conclude by mentioning an article authored by both Elizabeth and Graham published in the Festschrift (2017) for Marinella Rocca Longo, the Director of our Master in Linguaggi del Turismo e comunicazione interculturale of the University Roma Tre where Graham had many disciples. The same is true for other universities in Italy especially Faculties of English or post-colonial studies as his book on the language of tourism is still considered fundamental and has been translated bringing him numerous invitations for interviews and key lectures.

Giuli Liebman Parrinello*

\footnotetext{
* Associate Professor Giuli Liebman Parrinello, Ph.D., Università Roma Tre, Italy, e-mail: giuliana.liebman@
} uniroma3.it 